\title{
Gender Role Attitudes of Female Students in Single-Sex and Coeducational High Schools in Istanbul
}

\author{
Ayse Burcin Erarslan • Bruce Rankin
}

This paper has been accepted for publication in Sex Roles and the final (edited, revised and typeset) version of this paper is published in Sex Roles, 69, 2013. All rights reserved. Published online: 24 March 2013

\# Springer Science+Business Media New York 2013

\begin{abstract}
This study examines the relationship between school type and gender role attitudes among 295 female high school seniors attending four high schools, two single-sex and two coeducational. The schools are located in Istanbul, Turkey, where a recent proposal to establish a system of girls' schools has sparked a lively public debate about the advantages of single-sex schooling as a means of addressing the problem of lower female educational attainment. The main research question is whether the gender composition of schools has an impact on gender role attitudes, which we operationalize as attitudes toward gender roles in three domains: Family life, work life, and social life. Statistical analysis based on multiple regression show that, net of family background characteristics, students attending single-sex schools have more egalitarian attitudes toward family life roles than coeducational students, but school type does not matter for work and social life role attitudes. The socioeconomic composition of schools is also important, with students attending schools in the high socioeconomic status (SES) neighborhood having more egalitarian views on gender roles in family and social life.
\end{abstract}

Keywords Gender role attitudes . High school . Single-sex schools . Coeducation. Socioeconomic background . Neighborhoods . Turkey

\footnotetext{
A. B. Erarslan $(*)$

Department of Psychology, Koç University, Rumelifeneri Yolu, Sariyer, Istanbul 34450, Turkey

e-mail: aerarslan@ku.edu.tr

B. Rankin

Department of Sociology, Koç University, Istanbul, Turkey

e-mail: brankin@ku.edu.tr
}

Introduction

The recent rise in the number of single-sex schools in the U.S. and in some European countries has fueled debates over the advantages and disadvantages of single-sex in comparison to coeducational schooling (Smithers and Robinson 2006; Smyth 2010). In Turkey, a country with a long history of separate schools for girls and boys that it abandoned over time, support for a return to single-sex education, especially for girls, has been increasing (Hurriyet 2004, 2010; Ntvmsnbc 2009). This has sparked similar and often highly politicized debates, such that school choice has become a major concern not only for families, but also for policymakers and government (Hurriyet 2010).

While academic benefits have received the bulk of public and scholarly attention (Riordan 2002; Lee and Bryk 1986), other outcomes have been studied all over the world. Particularly since some socialization into adult gender roles occurs in schools, studies have also examined how school types impact gender role attitudes and beliefs (e.g., Hartman 2010; Karpiak et al. 2007; Brutsaert 1999; Lee and Bryk 1986). While most of the debates surrounding single-sex schooling in Turkey have ignored scholarly work on the subject (Kiziltas 2012), in fact there is little consensus in the empirical research from different countries on the benefits of single-sex education (Smyth 2010). A review of that body of research findings and a discussion of the ideological differences driving much of the research, as well as the methodological problems associated with sorting out student and school-level effects, is summarized in Part 1 of a special issue on single-sex education in the journal Sex Roles (Bigler and Signorella 2011).

The purpose of this study is to assess whether there are differences in the gender role attitudes of high school females who attend single-sex schools, in comparison to coeducational schools. The data analyzed come from a sample of 295 female high school students collected from two girls' 
schools and two coeducational schools located in Istanbul, Turkey. The concept of gender role attitudes is operationalized as having three domains, related to family life, work life, and social life, where the impact of school types on these three domains is assessed while controlling for family and neighborhood characteristics that are potentially associated with both school choice and gender role attitudes.

The study is significant, in part, because of the unique societal context that the case study provides. In contrast to most previous studies, this is a society where traditional gender ideology and practices persist among many segments of the population (Esmer 2011; Ermis 2009). Since 2002, the country has been led by a moderate Islamic, but socially conservative, government that some fear seeks to roll back the improvements in the status of women in Turkey, in part through instituting gender-specific educational programs (Vatan 2011; Hurriyet 2010). As such, it is a setting where widely divergent and highly contested views on gender and gender roles are held. The results of the current study will add to the existing knowledge about whether school type matters in the construction of gender role attitudes.

\section{Gender Composition of Schools and Gender Role Attitudes}

The choice between single-sex education and coeducation has potentially important implications for the gender socialization of adolescents. Theories of gender-role development underline the impact of environment on the formation of gender roles (Kirrane and Monks 2008; Lorber 2007; Eagly 1987). Implementation of single-sex schooling requires evidence-based arguments to be put into practice by the policy makers and educators, yet such evidence is lacking in many parts of the world (Halpern et al. 2011). The reviews on the outcomes of single-sex and coeducational schools in English-speaking countries, such as the U.S., Britain, Australia, New Zealand and Ireland, are inconclusive with respect to students' academic and psychological outcomes (Smyth 2010). Proponents of coeducation argued that single-sex settings run the risk of reinforcing gender stereotypes and traditional roles. As Halpern et al. (2011, p. 1707) explain, "the contrast between the segregated classroom and the mixed-sex structure of the surrounding world provides evidence to children that sex is a core human characteristic along which adults organize education". This echoes earlier claims by coeducational school proponents about the more realistic and socially integrated environment of coeducational settings (Dale 1971). Those who favor coeducation argue that single-sex schools are not realistic environments because in real life girls and boys need to learn to interact in cooperative and competitive ways and this ability is improved through their socialization in coeducational schools (Dale 1971). When they are isolated in single-sex schools, girls not only gain less experience in navigating a gendered world, but the school environment itself is assumed to foster traditional gender roles (Lee et al. 1994). A study of the Latin American context goes even further, claiming that single-sex education helps to ensure the sexual division of labor in society, and that alternatively coeducation is a way to ameliorate this unequal relationship between genders (Sara-Lafosse 1992).

However, several studies contradict that view and provide support for the proponents of single-sex education. Hartman (2010) investigated the impact of school type on students' gender role beliefs, as well as their academic and career objectives. She studied 100 female college students attending a U.S. Catholic college who were graduates of both single-sex and coeducational high schools. The findings revealed that girls who attended single-sex high schools had less traditional views about gender roles, a more positive self-concept, and put a greater emphasis on academic/career success than girls who attended coeducational high schools. She reported that girls from single-sex schools tend to have less traditional views about roles of women and more likely to agree that "women should have a place in the workforce and not feel tied to the role of caretaker" (Hartman 2010, p. 28).

Another study, conducted with students in Belgium in 43 single-sex and 25 coeducational secondary schools, found that there was a greater likelihood for adolescent girls to "enhance their gender identity" in coeducational than in single-sex schools, and they were more compliant with traditional female values and behavioral expectations in mixed school environments (Brutsaert 1999, p. 351). He concludes that stereotyped gender attitudes and behaviors are more pronounced in coeducational schools because gender boundaries are drawn more rigidly in the activities and other daily practices in coeducational schools.

In a study conducted with 1,220 college students in Japan, Katsurada and Sugihara (2002) examined the effects of gender-segregated school backgrounds on gender-role identity and attitudes toward marriage. The authors assumed that students perceive various roles in school according to gender and this is usually apparent in coeducational schools in such a way that gender comparisons are made more often between male and female students. In contrast, in gendersegregated schools students have to assume both male and female roles, which led the authors to find that women who graduated from single-sex high schools have nontraditional gender role identities and more liberal attitudes toward age for marriage than those who graduated from coeducational high schools.

Research on school environments in the U.S. has also called attention to how unacknowledged social practices in coeducational secondary schools serve to reproduce gendered outcomes (Lee et al. 1994). The "natural setting" 
argument of the coeducation proponents has been refuted by empirical evidence coming from U.S. samples, showing how differential expectations and treatment by teachers, gender-segregated activities and gendered subject choice violate the gender equality claimed to exist in coeducational schools (Sadker and Sadker 1994). Coeducational schools often foster traditional gender roles by reinforcing submissive roles for girls, who are dominated by boys in the classroom, whereas female students in single-sex settings receive more attention and are given more developmental opportunities (Hartman 2010).

Nonetheless, there are also some studies which have found no difference between single-sex and coeducational schools in terms of adolescents' gender-role attitudes. In Karpiak et al.'s (2007) study at a coeducational university in Pennsylvania, the authors expected women from singlesex high schools to have more egalitarian attitudes than those from coeducational high schools, but the results revealed no significant differences between the two groups. Evidence from a gendered classroom longitudinal study reports similar results. Signorella et al. (1996) studied single-sex and mixed classes in a private, non-religious school in the U.S., comparing adolescents' gender role stereotyping in the second through twelfth grades. There was significant decrease over time in stereotyping as measured by students' attitudes toward gender roles in both single-sex and mixed classrooms, suggesting that there were no detrimental effects of gender composition of classes on gender stereotyping.

In sum, there has been no clear consensus on the effects of school types on gender role attitudes, with some finding less stereotypic gender role attitudes for both single-sex school students and coeducational school students, and others finding no difference among the two. It is also important to note that a close comparison of the studies suggests a number of problems that might explain the discrepancies, including the lack of representative samples, and methodological deficiencies, particular to the difficulty of disentangling the effects of school type and student- and school-level selection effects. In addition, findings may be context-specific, making any generalizations about school type and gender attitude outcomes difficult.

\section{The Turkish Educational Context}

Following the establishment of the Turkish Republic in 1923, reforms were instituted that granted women access to education and employment and the right to vote, yet these benefits have not been equally shared by all women (Kagitcibasi 1998). Although the state has been successful in nearly erasing gender gaps in education, such that the proportion of male and females attaining primary, secondary, and post-secondary levels is roughly equal (Tan 2007), these developments did not necessarily improve the status of women in other spheres. In general, women are poorer and participate less in the labor force and in politics (Turkish Statistical Institute 2011; UNDP Human Development Report 2011; The Corporate Gender Gap Report 2010). Thus, despite the educational gains, large gender disparities persist in Turkey (Kagitcibasi 1998).

Turkey has a long history of separate schools for boys and girls. However, over time, the state adopted coeducational schools to ensure that girls and boys receive the same educational opportunities (Koca et al. 2005). By 1997, most of the remaining single-sex schools became coeducational, following the so-called 'February 28 process', a military intervention intended "to prevent Turkey from falling in the hands of Muslim fundamentalists" (Jung and Piccoli 2001, p. 118). Various educational reforms came afterwards, including the increase in compulsory primary education from 5 years to 8 years, closure of the secondary school system's religious schools (known as "imam-hatip" in Turkish) and Quranic courses, and the transformation of single-sex schools into coeducational ones (Altunisik and Tur 2005). However, in the last decade, both government and non-governmental organizations have been actively promoting the education of girls as a means of addressing the persistent gender gap in schooling (Tan 2007).

The debate over single-sex and coeducation in Turkey reignited in 2009 in response to the governor of Mardin province's proposal to open girls' schools in some regions of Turkey. The governor argued that the strong patriarchal traditions and beliefs of families living in southeastern Turkey do not allow girls to go to school. As such, he argued that if schools are separate for boys and girls, families would allow their girls to go to school (Ntvmsnbc 2009). The Minister of Education, Nimet Cubukcu, stated she did not oppose the practice of separate schooling. After her comments, various social commentators criticized the stance, seeing it as the advance of a new wave of Islamism that seeks to separate men and women in public settings, starting with schools. These worries intensified when news appeared in the newspapers about a high school headmaster in the southern city of Mersin stated that, at school, male and female students can be no closer than $45 \mathrm{~m}$ (Vatan 2011). These instances exacerbated concerns about the course of events in Turkey and the perception of an increasingly conservative and patriarchal governance under the Justice and Development Party government since their election in 2002.

Unfortunately, the politicized debate about opening girls' schools proceeded with little social scientific evidence. Although such proposals are mostly based on pedagogical reasons in other countries, such as the achievement levels of girls or improvement in self-concept, in Turkey, the arguments are mainly ideological. Those who are against single- 
sex institutions usually worry that single-sex schools incorporate traditional gender ideology and violate the secular system which purports to promote gender equality. Singlesex settings are considered unnatural and discriminatory, since the basic idea of separating genders is thought to violate equality between men and women.

On the other side of the debate are those who praise the benefits of single-sex schools, arguing that the conservatizing influence of the religious schools on girls is the result of their curriculum and not the fact that they are single-sex. Rather than sending girls to religious schools, they should be sent to single-sex schools with a modern curriculum that would promote gender equality and provide necessary skills and modern world views to facilitate women's full participation in society (Acar et al. 1999). In other words, some pro-girls' school scholars view girls' schools as a viable alternative to any kind of religious education (Acar et al. 1999).

One issue in the debate about single-sex education is the possible confounding factor of girls' selection into these schools. It has been argued that some school and studentrelated variables' effects are difficult to disentangle from the effects of single-sex education (Hayes et al. 2011). In Turkey, students select single-sex schools after taking a national examination. Every school has a limited quota for admitting students depending on the size of the school (both physical and in terms of number of teachers and classrooms). Those who score above a certain point can register to these schools. Another criterion is the need to be a resident of the neighborhood. Beginning in the 2009-2010 academic year, students are being placed into schools that are located in the neighborhoods which are closest to students' residences. The families then have a choice as to whether their children attend single-sex or coeducational schools in their neighborhoods.

\section{Gender Roles in Family, Work, Social Life}

Previous research suggests that differences in gender roles are especially apparent in male and female roles in family life, marriage, work life, and social life domains (Yilmaz et al. 2009; Vefikulucay et al. 2007; Dokmen 2004). Different aspects of gender role attitudes, including attitudes toward the division of household labor (Bjarnason and Hjalmsdottir 2008), attitudes toward marriage (Katsurada and Sugihara 2002), work-related attitudes (Kirrane and Monks 2008), and attitudes toward male and females in social life (Yilmaz et al. 2009) have been extensively investigated.

Connell (1994) argued that gender permeates all aspects of social life and gender constructions are at play in many settings, including family, workplace, the streets and shopping malls. Connell's framework suggests that there is nothing static or uniform about gender relations in these different spheres of life. In other words, different gender regimes may contradict or complement each other, such that household division of labor may be highly gendered, whereas in the workplace, male and female responsibilities may be undifferentiated. This is important to note because it cautions us that change in one sphere may not be reflected in other spheres. The relative autonomy of life domains was taken into account while formulating the present study's hypotheses.

National surveys show that traditional gender ideology is widely accepted in Turkey (Esmer 2011; UNDP Human Development Report 2011; The Corporate Gender Gap Report 2010). With respect to gender roles in family life, according to the 2011 World Values Survey, $74 \%$ of the adult population believe that men should be the head of the family (Esmer 2011). While women are encouraged to enter the labor force and establish their own businesses, $52 \%$ of men and $45 \%$ of women think that it is a problem for a married couple if the woman earns money more than her husband. On the other hand, $62 \%$ of the sample agreed that the best way for a woman to become an independent individual is to have a job (Esmer 2011). These statistics indicate that in different life domains both traditional and egalitarian views on gender roles coexist in the Turkish population.

\section{Family Background and Gender Role Attitudes}

The basic tenet of socialization theory is that values and attitudes are transmitted from the family to the children. Many of the socialization processes that influence the children's attitudes, values, and ideologies are found to be affected by the background of their parents, such as their education, ethnic origin, employment status and the like (Eccles et al. 1990; Kulik 2002).

Studies that compare single-sex and coeducational schools need to control for preexisting differences among students who attend these schools (Crosby et al. 1994). The socioeconomic status of the family is often cited for its impact on adolescents' egalitarian gender role attitudes (Antill et al. 2003; Kulik 2002). In studies where family income was taken into account, a positive association was found between family income and children's gender role attitudes. In other words, children from more economically advantaged family backgrounds had more egalitarian gender attitudes (Antill et al. 2003). The socioeconomic background of family is important for "internalization of gender roles" (Brutsaert 1999, p. 345). Research shows that gender socialization practices vary by parental socioeconomic status (SES), with higher SES children having more flexible views regarding gender roles, whereas a sharper distinction between male and female roles and responsibilities is more prevalent among lower SES 
children (Lindsey 1994). Lower family income has been found to be associated with more traditional attitudes towards gender, especially in the division of labor in family. Moreover, using data from 200 U.S. high school students, Sterrett and Bollman (1970) found a significant relationship between family social status and marriage role expectations of adolescents, with adolescents coming from lower status families having more traditional marriage role expectations.

Given the assignment of family care-giving roles to women, previous research has emphasized the influence of mothers on children (Arditti et al. 1991). Relationships have been found between mothers' level of education, employment status and gender-role attitudes of children (Corder and Stephan 1984). Maternal education was found to be positively associated with nontraditional attitudes among daughters (Kiecolt and Acock 1988). Zuckerman (1981) reports that the mothers' level of education strongly predicted their college student daughters' educational and career goals. Herzog and Bachman (1981) used data from the "Monitoring the Future" project and found that the gender role attitudes of high school seniors were related to their mothers' levels of education. An indirect effect of maternal education was also found in Jan and Janssens' (1998) study of adolescents and their mothers in the Netherlands regarding gender role attitudes toward motherhood and women's role in general. Collectively, these studies highlight the importance of family background variables, particularly family SES and the influence of maternal education on their daughters' views about gender roles.

\section{School and Neighborhood Socioeconomic Status}

As far as school-level factors are concerned, research shows that many developmental and educational outcomes are related to the socioeconomic composition of schools and neighborhoods (Montt 2012; Brooks-Gunn et al. 1993; Coleman et al. 1966). These contextual settings vary among schools, and may be linked to differences in school gender socialization processes (Alwin and Otto 1977). Although not related to gender outcomes, a research on the effects of school composition conducted in Belgian secondary schools suggest that a higher concentration of students from middle and upper middle classes improves school bonding and peer relationships (Brutsaert and Van Houtte 2002). With respect to academic achievement, higher socioeconomic composition of school was found to lead to better student outcomes (Montt 2012). Using data from 2000 to 2009 waves of OECD's Programme of International Student Assessment (PISA), Montt (2012) found that students attending more advantaged schools show better achievement and higher status expectations.
Wilson's (1987) study of urban neighborhoods in U.S. cities highlighted how neighborhood socioeconomic and cultural characteristics influence many adult and youth outcomes. This insight is relevant to the present study since the selected schools are located in one low and one relatively high income neighborhood. As such, a comparison of single-sex and coeducational schools within each of these neighborhoods must factor in whether any observed differences in gender attitudes are due to school effects or to the socioeconomic status composition of the schools in a particular neighborhood.

Based on the above discussion of the relevant theoretical arguments and empirical research conducted in different parts of the world, we hypothesize that girls in single-sex schools will have more traditional attitudes toward family life (Hypothesis 1), but more egalitarian attitudes toward work life (Hypothesis 2) and social life (Hypothesis 3), compared to those in coeducational schools. The theoretical justification for the differentiation between these domains of family, work and social life attitudes comes from Connell (1994).

In Turkey, where traditional attitudes are widely shared, schools are expected to reflect societal norms (Acar and Ayata 2002) and infuse students with messages about motherhood and the caregiver role of women. As such, the single-sex schools are expected to emphasize womanhood and the care giver role of women (i.e., Hypothesis 1). With regard to work and social life (i.e., Hypotheses 2 and 3), the literature suggests that girls from single-sex schools are more career-oriented and single-sex schools foster less stereotyped gender roles for women (Hartman 2010; Francis et al. 2003; Katsurada and Sugihara 2002; Brutsaert 1999; Elwood and Gipps 1999; Mael 1998; Sadker and Sadker 1994; Delamont 1990; Lee and Marks 1990; Lee and Bryk 1986). Previous research demonstrate that girls in single-sex schools have more interest in academics and have better academic performances (Lee and Marks 1990), feel more comfortable in participating in all lessons and activities free from boys' distractions (Hughes 2006; Vail 2002); and, girls break out of their traditional roles by speaking up and becoming leaders (as cited in Vail 2002). As such, we expect girls in single-sex schools to be supportive of multiple roles of women, including career orientation and active participation in the work force and social life.

A large body of research reports a positive association between socioeconomic status and egalitarian gender role attitudes (Brutsaert and Van Houtte 2002; Alwin and Otto 1977; Lindsey 1994), which leads us to hypothesize that students from higher SES families, as measured by parental education and household income, and from schools in higher SES neighborhoods will have more egalitarian gender role attitudes, compared to those from lower SES 
families and from schools in lower SES neighborhoods (Hypothesis 4 and 5, respectively).

\section{Method}

Sample

The data analyzed in this study come from four Istanbul public high schools located in two neighborhoods. Since we were interested in examining the effects of school gender composition in different socioeconomic contexts, we selected one girls' and one coeducational school located in a high socioeconomic neighborhood of Erenkoy, with similarly privileged students, and one each from a low socioeconomic neighborhood of Fatih, composed of more disadvantaged students. The choice of schools and neighborhoods was largely determined by our interest in the gender regimes of formal, non-vocational schools. As such, we excluded other schools (e.g., religious, vocational and technical, and elite math and science schools), leaving two general public girls' high schools and two coeducational schools. In both neighborhoods, the schools are within walking distance of each other.

Within each of the schools, a listing of classes from different tracks (i.e., Turkish-Math, Science-Math, and Social Sciences) was created and one class from each track was selected randomly. In order to make the number of girls in single-sex and coeducational schools more comparable, two more classes were chosen from the coeducational schools. In the end, three classes from Fatih Girls' High School $(N=91)$, three classes from Erenkoy Girls' High School $(N=85)$, five classes from Ahmet Rasim High School $(N=61)$, and five classes from Intas High School $(N=58)$ were selected.

The survey data also included responses of male students, though they are not examined in this study. The final sample is composed of a total of 295 female students in the 12th grade of the four public high schools.

\section{Procedure}

The students were surveyed using a 94-item selfadministered questionnaire where demographic, socioeconomic and attitudinal questions were asked. The questionnaire is a theoretically-grounded instrument, which was constructed based on questions used in previous research. In the construction of the questionnaire, studies conducted in Turkey and in different parts of the world were used as a guide (Yilmaz et al. 2009; Krivickas and Sanches 2008; Vefikulucay et al. 2007; Baber and Tucker 2006; Phinney and Flores 2002; Jackson and Tein 1998; Spence and Hahn 1997; Suzuki 1991; Amato 1988; Larsen and Long 1988).
The theoretical framework and the preparation of the questionnaires were completed in the fall of 2010. Government permission to conduct the study was granted in December 2010. The first visits to schools started in January 2011 and finished in May 2011. School administrators and counselors were given a briefing about the study, who then arranged the time to conduct the surveys, making sure that the questionnaires were completed during school hours in weeks when students do not have examinations.

\section{Measures}

\section{Gender Role Attitude Variables}

We assessed students' beliefs about male and female attributes, abilities, and roles in work, family, marriage, and social life settings with 32 separate questions regarding their agreement, or not, with various gender role statements. Many of the items replicate work cited above, while others were altered or created to fit the Turkish context. An exploratory factor analysis led us to eliminate eight items with low loadings (i.e., <.3) or that loaded on more than one factor, resulting in 3-factor solution closely paralleling the three attitudinal domains around which the original survey was designed. Thus, we operationalized gender role attitudes using three indices of attitudes toward family life, work life, and social life. The indices are summations of related items, all of which have identical Likert-type response categories, ranging from 1 ("strongly agree") to 4 ("strongly disagree"). Items are coded such that lower values indicate a more traditional orientation and higher values a more egalitarian position. The resulting indices all have acceptable alpha reliabilities (i.e., greater than .7).

The gender role attitude indices range along a continuum from traditional to non-traditional or egalitarian views. In order to minimize response bias and to differentiate between the relatively traditional and egalitarian views, efforts were made to include items that measure both ends of the continuum. Approximately half of the items representing a more egalitarian point of view, with agreement signifying opposition to rigidly-defined traditional roles (e.g., "having a challenging job or career is as important as being a wife and mother"). The remainder represents a traditional point of view which assigns women the role of housekeeper and caregiver (e.g., "it is usually better for everyone involved if the man is the achiever outside the home and the woman takes care of the home and family" and "a woman should not be employed if her husband can support her"). For a complete list of items for each index, factor eigenvalues, and item loadings, see Appendix A.

The nine-item family life index, for the most part, assesses student attitudes regarding family roles and 
responsibilities. For example, the index includes responses to such statements as "the husband should be the head of the family", "a woman's most important task in life is being a mother", and "by nature, women are better than men at making a home and caring for children" (Krivickas and Sanches 2008). The variable ranges from 9 to 36 and has a Cronbach's alpha of .76.

The ten-item work life index centers on attitudes towards female employment and its impact on the family. It includes questions such as "having a job is just as important for a wife as it is for her husband" (Larsen and Long 1988), "a mother who stays home and raises children is not the only ideal type of mother" (Suzuki 1991) and "a husband should share equally in household chores if his wife works full time." Since lower scores indicate less egalitarian responses, we reverse-coded the items prior to summing them, such that higher scores on the resulting index indicates more egalitarian views on work life attitudes. The index ranges from 10 to 40 and has a Cronbach's alpha of .76 .

The five-item social life index is composed of questions that assess attitudes towards female independence in social life and sexual morality, with statements such as, "a widowed or divorced woman should not live alone" (Yilmaz et al. 2009), "a woman should not walk alone at night in the streets" (Yilmaz et al. 2009), and "the woman a man will marry should be a virgin". While these may sound anachronistic, they reflect widely-held moral judgments in Turkish society. The social life index ranges from 5 to 20 , with an alpha of .71 .

To preserve cases, respondents that had a value missing on only a single item were retained and their resulting index was adjusted upward to be proportional to what the score would have been with valid data on the missing item. Our adjustment assumes that the proportionate score is the best estimate.

\section{Family Background Variables}

Two family background variables are used in the analysis: Net monthly household income and maternal education. Preliminary analysis indicated that maternal education explained more variance than fathers' education in daughters' gender role attitudes, a finding that is consistent with other studies (Kulik 2002; Jan and Janssens 1998; Kiecolt and Acock 1988; Herzog and Bachman 1981). As such, to reduce the potential collinearity, only maternal education is used in the analyses below. Both of the variables are ordinal measures, with the 4-category maternal education variable coded as follows: $1=$ primary school or less, $2=$ junior high graduate, $3=$ high school graduate, $4=$ university or higher degree. To test for nonlinear education effects, we also created three dummy variables for junior high, high school, and university or higher, with primary school or less as the excluded category. The household income variable is 6-category grouped variable ranging from no income to more than 5,000 Turkish Lira, which at the time of the survey was equivalent to $\$ 3,126$. Instead of creating a composite score by aggregating the two variables, namely maternal education and household income, both of the variables were preserved at their original level of measurement.

\section{Results}

\section{Descriptive Statistics}

Table 1 displays descriptives and statistical tests for variables used in the regression analysis. Looking at the mean school scores for attitudes regarding family, work, and social life, students in high SES schools (Erenkoy and Intas) hold somewhat more egalitarian attitudes compared to students in schools in low SES Fatih neighborhood, particularly in family and social life attitudes. Differences between school types are much smaller. In order to test whether school means of the dependent variables are significantly different, a one-way ANOVA was conducted. F-tests indicate that all three models where statistically significant: family life, $F(3,287)=12.81, p<.000$; work life, $F(3,288)=2.70, p<.05$; and social life, $F(3,285)$ $=10.70, p<.000$. Significant school differences in family life index means are obtained. Post hoc Tukey tests revealed that the differences are mostly between low SES and high SES schools, instead of differences by type of school. Only two of the paired differences involved different school types. Specifically, the family and social life means for Erenkoy are different from both low SES schools, Fatih and Ahmet Rasim; the mean for Ahmet Rasim is different for Intas for both indices as well. The social life mean for Fatih is also different from Intas. No significant differences were found for the work life means.

As discussed above, two of our schools are located in the high SES neighborhood of Erenkoy and two in the lower SES neighborhood of Fatih. As expected, these socioeconomic differences are also observable in the family background of the students in these schools, as our results indicate. While the chi-square tests demonstrate that both measures are not independent of schools, a closer inspection of the figures shows that most of the differences are between neighborhood and less between school types. Net monthly household income and maternal educational levels for those attending the two schools in Fatih are relatively low compared to those attending the two schools in Erenkoy. The differences between school types are much smaller. 
Table 1 Sample descriptives and ANOVA and chi-square statistical tests (standard deviations are in parentheses)

\begin{tabular}{|c|c|c|c|c|}
\hline & \multicolumn{2}{|c|}{ Single-sex } & \multicolumn{2}{|l|}{ Coed } \\
\hline & Fatih & Erenkoy & A. Rasim & Intas \\
\hline \multicolumn{5}{|c|}{ Gender role attitude indices (mean/SD) } \\
\hline Family life (range 9-36) & $23.6^{\mathrm{ab}}$ & $26.4^{\mathrm{c}}$ & $21.9^{\mathrm{a}}$ & $24.7^{\mathrm{bc}}$ \\
\hline$F(3,287)=12.81, p<.000$ & $(4.5)$ & $(4.2)$ & $(4.5)$ & $(4.4)$ \\
\hline Work life (range 10-40) & 33.8 & 34.2 & 32.6 & 34.3 \\
\hline$F(3,288)=2.70, p<.050$ & $(3.4)$ & $(4.3)$ & $(4.2)$ & $(3.2)$ \\
\hline Social life (range 5-20) & $12.1^{\mathrm{a}}$ & $13.9^{\mathrm{b}}$ & $11.9^{\mathrm{a}}$ & $14.4^{\mathrm{b}}$ \\
\hline$F(3,285)=10.70, p<.000$ & $(3.3)$ & $(3.5)$ & $(2.3)$ & $(3.1)$ \\
\hline \multicolumn{5}{|l|}{ Family SES Characteristics } \\
\hline \multicolumn{5}{|l|}{ Mother education (\%) } \\
\hline Primary school and less & 73.6 & 21.2 & 60.7 & 22.4 \\
\hline Junior high school & 12.1 & 20.0 & 27.9 & 22.4 \\
\hline High school & 14.3 & 38.8 & 9.8 & 32.8 \\
\hline University and higher & .0 & 20.0 & 1.6 & 22.4 \\
\hline \multicolumn{5}{|l|}{$\mathrm{X}^{2}(9, N=295)=89.00, p<.001$} \\
\hline \multicolumn{5}{|l|}{ Monthly income (\%) } \\
\hline Less than $1,000 \mathrm{TL}^{\mathrm{d}}$ & 12.7 & 4.4 & 16.3 & 8.2 \\
\hline $1,000-20,000 \mathrm{TL}$ & 50.7 & 29.4 & 61.2 & 44.9 \\
\hline $2,000-3,000 \mathrm{TL}$ & 21.1 & 25.0 & 18.4 & 30.6 \\
\hline $3,000-4,000 \mathrm{TL}$ & 8.5 & 23.5 & 2.0 & 6.1 \\
\hline $4,000-5,000 \mathrm{TL}$ & 2.8 & 5.9 & 2.0 & 2.0 \\
\hline More than 5,000 TL & 4.2 & 11.8 & .0 & 8.2 \\
\hline \multicolumn{5}{|l|}{$\mathrm{X}^{2}(5, N=237)=22.05, p<.001$} \\
\hline$N$ & 91 & 85 & 61 & 58 \\
\hline
\end{tabular}

abc Gender role attitude index means with the same letter in the superscript do not differ significantly from one another based on post hoc Tukey tests at the .05 level

${ }^{\mathrm{d}}$ At the time of the survey, 1,000 Turkish Lira was equivalent to $\$ 630$

\section{Correlations}

Table 2 shows the bivariate correlations between our independent and dependent variables for the two school types separately, with the single-sex school correlations above the diagonal and the coeducational school's below the diagonal. In both schools, most of the correlations between the gender role attitudes indices are significantly correlated, but not highly so, which supports the claim that these are distinct domains

Table 2 Correlations for single-sex schools (upper diagonal) and coeducational schools (lower diagonal)

\begin{tabular}{llllll}
\hline Variable & 1 & 2 & 3 & 4 & 5 \\
\hline 1. Family life index & - & $.20^{*}$ & $.41^{* *}$ & $.23^{* *}$ & .13 \\
2. Work life index & $.27^{* *}$ & - & .08 & .03 & .16 \\
3. Social life index & $.43^{* *}$ & $.22^{*}$ & - & $.32^{* *}$ & $.33^{* *}$ \\
4. Maternal education & $.26^{* *}$ & .17 & $.45^{* *}$ & - & $.43^{* *}$ \\
5. Household income & $.30^{* *}$ & $.25^{*}$ & $.36^{* *}$ & $.43^{* *}$ & - \\
\hline
\end{tabular}

${ }^{*} p<.05,{ }^{* *} p<.01$ of gender role attitudes that should be analyzed separately (Connell 1994). Across schools, all gender attitude indices are correlated with one or both of the family background variables (i.e., maternal education and income), with the exception of the work life index for single-sex schools.

\section{Regression}

Our school-level means and ANOVA results reported above suggest that both school type and neighborhood SES may be associated with gender role attitudes of the students attending these high schools. To test this, we constructed two dummy variables, one indicating a single-sex school (i.e., $1=$ single-sex, $0=$ coeducational) and one indicating high SES neighborhood (i.e., $1=$ high SES, $0=$ low SES). Table 3 reports the ordinary least-squares regression of our three attitudinal indices on the family background, school type, and neighborhood SES factors to try to answer our first research question: Is there a relationship between school and neighborhood types and gender-role attitudes, after 
Table 3 Regression analysis predicting egalitarian gender role attitudes

\begin{tabular}{|c|c|c|c|c|c|c|c|c|c|c|c|c|}
\hline \multirow[t]{2}{*}{ Variable } & \multicolumn{4}{|c|}{ Family life } & \multicolumn{4}{|c|}{ Work life } & \multicolumn{4}{|c|}{ Social life } \\
\hline & $B$ & $S E \mathrm{~B}$ & $\beta$ & VIF & $B$ & $S E \mathrm{~B}$ & $\beta$ & VIF & $B$ & $S E \mathrm{~B}$ & $\beta$ & VIF \\
\hline Mothers with junior high school degree & -.02 & .85 & -.00 & 1.29 & .31 & .74 & .03 & 1.29 & -.76 & .59 & -.09 & 1.29 \\
\hline Mothers with high school degree & .27 & .81 & .03 & 1.51 & .64 & .71 & .07 & 1.54 & .99 & .56 & .13 & 1.54 \\
\hline Mothers with university and higher degree & 1.44 & 1.15 & .10 & 1.54 & -.76 & .99 & -.06 & 1.56 & $2.09 * *$ & .78 & .20 & 1.59 \\
\hline Household income & .00 & .00 & .10 & 1.27 & $.00 * *$ & .00 & .18 & 1.28 & $.00 * *$ & .00 & .21 & 1.29 \\
\hline Single-sex schools & $1.26^{*}$ & .60 & .14 & 1.06 & .15 & .52 & .02 & 1.06 & -.12 & .41 & -.02 & 1.06 \\
\hline High SES neighborhood & $1.81 * *$ & .68 & .20 & 1.39 & .34 & .60 & .04 & 1.41 & $1.04^{*}$ & .47 & .16 & 1.43 \\
\hline$R^{2}$ & .11 & & & & .05 & & & & .22 & & & \\
\hline $\mathrm{N}$ & 232 & & & & 232 & & & & 228 & & & \\
\hline
\end{tabular}

$* p<.05 ; * * p<.01$

differences among students in income and maternal educational level have been statistically eliminated? Variance inflation factors reported in Table 3 indicate that collinearity is not a problem in any of the models.

Starting with the family life index model $\left(R^{2}=.11\right), F$ $(6,231)=4.78, p=.000$, the results show that going to a girls' school and attending school in a high SES neighborhood were significant predictors of students' egalitarian gender role attitudes toward family life, with the neighborhood SES somewhat larger $(\beta=.20)$ than single-sex school type effect $(\beta=.14)$. None of the family background variables had significant effects. These variables explained $11 \%$ of the variance in students' gender role attitudes toward family life. Substantively, the results indicate that students going to single-sex school had more egalitarian attitudes than those going to coeducational schools, a result contrary to what was expected in Hypothesis 1. The hypothesized effect of neighborhood SES was supported, as students in higher SES neighborhoods had more egalitarian attitudes compared to those in lower SES neighborhoods. In results not presented here, we also tested the interaction between school type and neighborhood SES, such that, for example, girls attending a single-sex school in a high SES neighborhood might have higher scores than would be predicted based only on the main effects of school type and neighborhood SES. The results showed that the interaction was not significant for any of the gender attitude index models (tables available upon request).

For the work life index, the overall model is marginally significant $\left(R^{2}=.05\right), F(6,231)=2.05, p<.06$. Contrary to Hypothesis 2, school type had no effect on work life attitudes. Only income was significant, such that students from higher income families had more egalitarian work life attitudes $(\beta=.18)$, as hypothesized (see Hypothesis 4$)$. The model explained $5 \%$ of the variation in students' scores related to gender roles in work life.

When students' gender role attitudes toward social life were regressed on family background variables, type of school and neighborhood SES, the overall model was significant, $\left(R^{2}=.22\right), F(6,227)=10.32, p<.001$. Since school type had no effect, Hypothesis 3 was not supported. However, the effects of both individual and neighborhood SES (Hypotheses 4 and 5) are supported. Both household income and having mothers with university or higher degree is associated with more egalitarian gender-role attitudes toward social life, as is going to school in a high SES neighborhood $(\beta=.21$,

.20 , and .16, respectively). Overall, these variables accounted for $22 \%$ of the variance in the dependent variable.

\section{Discussion}

In Turkey and elsewhere, the pros and cons of single-sex and coeducation remains a matter of continuing debate. The present study focused on one of the critical issues in that debate, contextual differences in gender socialization and how those differences may shape gender role attitudes. We focused on female high school students in four single-sex and coeducational schools in Istanbul, examining whether gender role attitudes with regard to family, work and social life are related to school type, family and neighborhood socioeconomic factors. Specifically, we found that the three domains of attitudes-family, work, and social-with respect to gender roles are differentiated, as Connell (1994) argues, and the relationships between family background, school and neighborhood and gender role attitudes varies depending on attitudinal domain. For some outcomes, the type of school was associated with more egalitarian gender role attitudes, whereas for other outcomes family background variables and location of school mattered more.

The regression analyses showed that going to a singlesex school and attending a school in high SES 
neighborhoods is associated with more egalitarian attitudes toward family life. Although previous findings on the relationship between SES and egalitarian attitudes (Antill et al. 2003; Alwin and Otto 1977) were supported, having egalitarian gender role attitudes toward family life in single-sex schools was a finding contrary to what we hypothesized given the more conservative cultural context of Turkey. While we should be cautious about generalizing from our results, it seems that fears that single-sex schools invariably reinforce the subservient status of Turkish women may be unwarranted.

With respect to women's roles and responsibilities in work life, and women's employment outside home and balancing work and home responsibilities, students' attitudes were only influenced by household income. This finding is supported by previous research which found positive association between high SES and aspirations to combine family and work roles (Corder and Stephan 1984). The sole effect of household income may indicate that students' attitudes about the multiple roles of employed women are shaped less by schools, than by other factors. Given that the variance explained in work life index is only $5 \%$, there are clearly other variables

influencing that attitudinal domain. Some studies have highlighted factors that reinforce traditional attitudes toward women's participation in work life, including social norms about appropriate jobs for males and females and the availability of jobs for women (Yilmaz et al. 2009); while others point to pressures and inequalities faced by women in workplaces and the lack of childcare facilities (Government Planning Institute and World Bank Report 2009). These constraints may help to shape adolescents' views about women's participation and status in work life.

The attitudes toward social life, on the other hand, were affected mostly by family background variables. Unlike the prior findings (Jan and Janssens 1998; Kiecolt and Acock

1988; Corder and Stephan 1984), this study found that maternal education only affected social life attitudes, but not family or work life attitudes. Family income, on the other hand, was more significant in affecting girls' attitudes toward work and social life. Girls of more educated and better-off families hold more egalitarian attitudes toward

women's status in social life. Neighborhood SES also mattered in predicting girls' gender role attitudes toward social life, with students in high SES neighborhood holding more egalitarian attitudes.

One implication of our findings is that policy-makers, proposing single-sex education, need to take into account the socioeconomic context. This may also contribute to the debates about the benefits of single-sex education for some groups in some contexts, but not the others (Riordan 2002). Since this study shows that the SES composition of the neighborhood and school made a difference in gender role attitudes, the context in which girls' schools are located needs to be evaluated carefully.

\section{Limitations and Future Directions}

In most of the research about single-sex and coeducation, major methodological problems include generalizability, confounding variables, selection bias, and inconsistency in comparative measures or indicators (Sax et al. 2009). Some of these problems exist in the present study and these methodological issues and limitations need to be noted.

Although the cross-sectional design of the present study gives a snapshot of female adolescents' attitudes toward gender in single-sex and coeducational school environments, a causal relationship cannot be drawn from these statistical analyses. Moreover, the results of the present study may only be generalizable to female populations at schools in comparable neighborhoods with similar demographics. Nonetheless, this study contributes new data to the research on gender role attitudes of adolescents, with a focus exclusively on the experience of female students from single-sex and coeducational high schools in Istanbul.

Future research on this topic would benefit from a more in-depth study of school environments, including curriculum and instructional materials, but also information that can only be gleaned through participant observation of the school environment to discover how gender is performed in classrooms, sports facilities and elsewhere. Research is also needed to address longer-term questions, such as whether gender role attitudes observed in high school change over the life course, for example, as women matriculate through college, enter the labor force, and form families. A followup study would help us to see if there is a discrepancy between student attitudes towards gender issues they will face as adults and actual behavior of those students at that life stage. Such a longitudinal design may provide better evidence of long-term advantages or disadvantages of attending single-sex versus coeducational schools.

Our findings have implications for the single-sex schooling debates globally, such that not only the general cultural context, but the context where a school is located at the micro level, i.e. neighborhoods, also matter. While the results give some support to the claim that single-sex schools can socialize students into more egalitarian family life gender roles, we cannot conclude that single-sex schooling is beneficial for all students. In sum, more research is needed on different aspects of single-sex and coeducation, particularly in Turkey, where more empirical studies are needed to inform political and policy debates over the benefits of one type of education over another. 
Appendix A

Table 4 Gender role indices

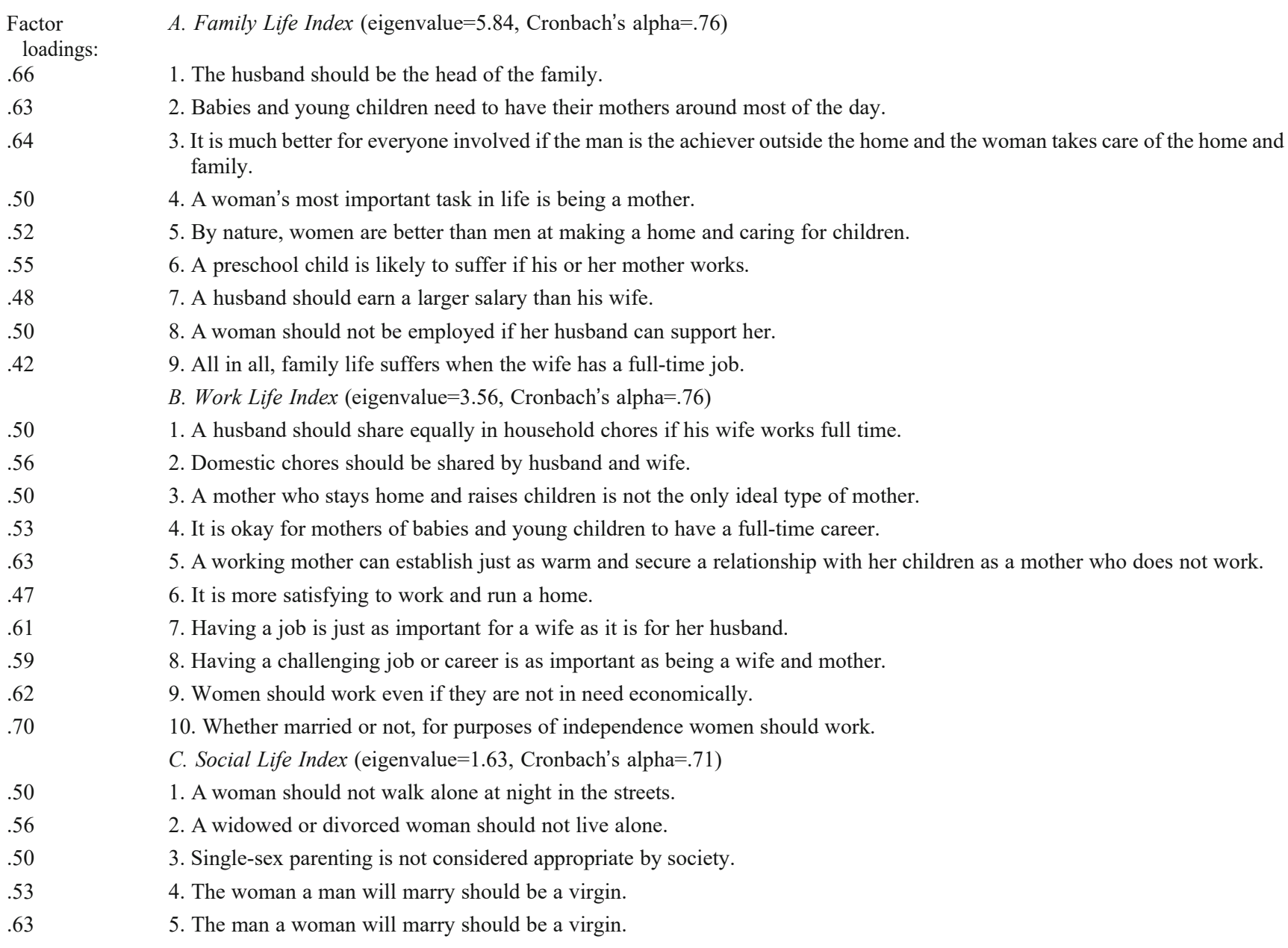

Response codes for all items are: $1=$ strongly agree, 2 = agree, $3=$ disagree, $4=$ strongly disagree . Eigenvalues and factor loadings are obtained from a principal-components factor analysis using an oblique promax rotation method

\section{Appendix B}

Aile hayatı $(\alpha=.76)(1=$ çok katılıyorum, $2=$ katılıyorum 3 = katılmıorum, $4=$ hiç katılmıyorum)

1. Ailenin reisi erkek olmalıdır.

2. Bebekli ve çocuklu anneler günün büyük bir kısmında evde olmalidir.

3. Erkeğin eve para getirmesi, kadının ev işleri ve çocuk bakımıyla ilgilenmesi herkes için en iyisidir.

4. Bir kadının hayattaki en önemli görevi anne olmaktır.

5. Yaradılıştan, ev işlerini yapmakta ve çocuk bakmakta kadınlar erkeklerden daha iyidir.

6. Çalışan bir anne olmak okul öncesi yaştaki çocuğu için zararlidir.

7. Bir erkek karısından daha fazla para kazanmalıdır.

8. Eğer erkek karısına bakabilecek maddi güce sahipse kadının çalışmasına gerek yoktur.
9. Kadın tam zamanlı bir iște çalıșırsa aile hayatı zarar görür.

$\dot{I}_{\text {Ş hayatı }(\alpha=.76)}(1=$ çok katıllyorum, $2=$ katıllyorum

$3=$ katılmıyorum, $4=$ hiç katılmıyorum)

1. Bir erkeğin karısı tam zamanlı çalışıyor ise erkek ev işlerinde yardım etmelidir.

2. Ev işleri karı koca arasında paylaşılmalıdır.

3. Ev kadını olmak ve çocuk büyütmek ideal olan tek annelik tipi değildir.

4. Bebeği ve çocuğu olan annelerin tam zamanlı bir kariyeri olabilir.

5. Çalışan bir annenin de çalışmayan anne kadar çocuklarıyla sıcak ve güvenli bir ilişkisi olabilir.

6. Aynı anda hem çalışmak hem eve bakmak bir kadını daha çok tatmin eder.

7. Bir iş sahibi olmak erkek için olduğu kadar kadın için de önemlidir. 
8. Bir kadın için zorlu ve firsatlarla dolu bir işte çalışmak, eş ve anne olmak kadar önemlidir.

9. Maddi gereksinimleri olmasa dahi kadınlar çalışmalı ve para kazanmalıdırlar.

10. Evli olsa da olmasa da bir kadın özgürlüğü için çalışmalıdır.

Sosyal hayat $(\alpha=.71)(1=$ çok katıliyorum, $2=$ katıliyorum $3=$ katılmıyorum, 4 = hiç katılmıyorum)

1. Bir kadın geceleri tek başına sokakta yürümemelidir.

2. Boşanmış veya dul kalmış bir kadın yalnız başına yaşamamalıdır.

3. Tek ebeveyn olmak (tek anne/tek baba) toplumca yadırganan bir durumdur.

4. Bir erkeğin evleneceği kadın mutlaka bakire olmalıdır.

5. Bir kadının evleneceği erkek mutlaka bakir olmalıdır.

\section{References}

Acar, F., \& Ayata, A. (2002). Discipline, success and stability: The reproduction of gender and class in Turkish secondary education. In D. Kandiyoti \& A. Sektanber (Eds.), Fragments of culture: The everyday of modern Turkey (pp. 90-111). New Brunswick: Rutgers University Press.

Acar, F., Ayata A., \& Varoglu D. (1999). Cinsiyete dayalı ayrımcilı: Türkiye'de eğitim sektörü örneği: Cinsiyete dayall ayrımcllık ve kadın çalışanlara karşı tutumlar: Türkiye'de eğitim sektörü örneği. [Gender-based discrimination: An education sector example from Turkey: Gender-based discrimination and attitudes toward working women: Education sector example from Turkey]. Ankara: TC Başbakanlık Kadının Statüsü ve Sorunları Genel Müdürlüğü.

Altunisik, M. B., \& Tur, O. (2005). Turkey: Challenges of continuity and change. London: Routledge Curzon.

Alwin, D., \& Otto, L. B. (1977). High school context effects on aspirations. Sociology of Education, 50, 259-273. doi:10.2307/2112499.

Amato, P. R. (1988). Parental divorce and attitudes toward marriage and family life. Journal of Marriage and Family, 50, 453-461. doi: $10.2307 / 352010$.

Antill, J. K., Cunningham, J. D., \& Cotton, S. (2003). Gender-role attitudes in middle childhood: In what ways do parents influence their children? Australian Journal of Psychology, 55, 148-153. doi:10.1080/0004953042000298602.

Arditti, J., Godwin, D., \& Scanzoni, J. (1991). Perceptions of parenting behavior and young women's gender role traits and preferences. Sex Roles, 25, 195-211. doi:10.1007/BF00289854.

Baber, K. M., \& Tucker, C. J. (2006). The social roles questionnaire: A new approach to measuring attitudes toward gender. Sex Roles, 54, 459-467. doi:10.1007/s11199-006-9018-y.

Bigler, R. S., \& Signorella, M. L. (2011). Single-sex education: New perspectives and evidence on a continuing controversy. Sex Roles, 65, 659-669. doi:10.1007/s11199-011-0046-x.

Bjarnason, T., \& Hjalmsdottir, A. (2008). Egalitarian attitudes towards the division of household labor among adolescents in Iceland. Sex Roles, 59, 49-60. doi:10.1007/s11199-008-9428-0.

Brooks-Gunn, J., Duncan, G., Klebanov, P., \& Sealand, N. (1993). Do neighborhoods influence child and adolescent development? American Journal of Sociology, 99, 353-395.

Brutsaert, H. (1999). Coeducation and gender identity formation: A comparative analysis of secondary schools in Belgium. British
Journal of Sociology of Education, 20, 343-355. doi:10.1080/ 01425699995308 .

Brutsaert, H., \& Van Houtte, M. (2002). Girls' and boys' sense of belonging in single-sex versus co-educational schools. Research in Education, 68, 48-56.

Coleman, J. S., Campbell, E. Q., Hobson, C. J., McPartland, J., Mood, A. M., Weinfeld, F. D., et al. (1966). Equality of educational opportunity. Washington, D.C.: US Department of Health Education and Welfare Office of Education.

Connell, R. W. (1994). Gender regimes and the general order. In Polity (Ed.), The polity reader in gender studies (pp. 29-40). Oxford: Polity Press \& Blackwell Publishers.

Corder, J., \& Stephan, C. (1984). Females' combination of work and family roles: Adolescent aspiration. Journal of Marriage and the Family, 56, 391-402. doi:10.2307/352471.

Crosby, F., Allen, B., Culbertson, T., Wally, C., Morith, J., Hall, R., et al. (1994). Taking selectivity into account, how much does gender composition matter? A reanalysis of M.E. Tidball's research. NWSA Journal, 6, 107-118.

Dale, R. R. (1971). Mixed or single-sex school? Some social aspects. Vol II. London: Routledge.

Delamont, S. (1990). Sex roles and the school. London: Routledge.

Dokmen, Z. Y. (2004). Toplumsal cinsiyet: Sosyal psikolojik açıklamalar. [Gender: Social psychological explanations]. Istanbul: Sistem Yayıncilik.

Eagly, A. (1987). Sex differences in social behavior: A social role interpretation. Hillsdale: Erlbaum.

Eccles, J., Jacobs, J., \& Harold, R. (1990). Gender role stereotypes, expectancy effects, and parents' socialization of gender differences. Journal of Social Issues, 46, 183-201. doi:10.2307/352471.

Elwood, J., \& Gipps, C. (1999). Review of research on the achievement of girls in single-sex schools. London: Institute of Education, University of London.

Ermis, A. (2009). The incompatibility of Turkish women's educational attainment and occupational participation. Hacettepe Üniversitesi Sosyolojik Araştırmalar Dergisi, 1-25.

Esmer, Y. (2011). Summary findings of the World Values Survey: Turkey. Retrieved from http://smgconnected.com/2011-turkiyedegerler-arastirmasi

Francis, B., Hutchings, M., Aarcher, L., \& Melling, L. (2003). Subject choice and occupational aspirations among pupils at girls' schools. Pedagogy, Culture and Society, 11(3), 425-442. doi:10.1080/14681360300200182.

Government Planning Institute \& World Bank Report. (2009). Female labor force participation in Turkey: Trends, determinants and policy framework. (Report No. 48508). Retrieved from http:/ siteresources.worldbank.org/TURKEYEXTN/Resources/3617111268839345767/Female_LFP-en.pdf

Halpern, D. F., Eliot, L., Bigler, R. S., Fabes, R. A., Hanish, L. D., Hyde, J., et al. (2011). The pseudoscience of single-sex schooling. Science, 333, 1706-1707. doi:10.1126/science.1205031.

Hartman, K. (2010). The advantages of single-sex vs. coeducational environments for high school girls. Social Work Student Papers, 63, 1-38. Retrieved from http://digitalcommons.providence.edu/ socialwrk_students/63.

Hayes, A. R., Pahlke, E. E., \& Bigler, R. S. (2011). The efficacy of single-sex education: Testing for selection and peer quality effects. Sex Roles, 65, 693-703. doi:10.1007/s11199-010-9903-2.

Herzog, A. R., \& Bachman, J. G. (1981). Sex-role attitudes among high school seniors: Views about work and family roles. Ann Arbor: Institute for Social Research.

Hughes, T. A. (2006). The advantages of single-sex education. National Forum of Educational Administration and Supervision Journal, 23(2), 5-14.

Hurriyet. (2004, March 12). Eğitim-Bir-Sen: Kız erkek ayrı okutulmalı [Educators Association Union: Girls and boys should be educated 
separately]. Retrieved from http://webarsiv.hurriyet.com.tr/2004/ 03/12/426890.asp

Hurriyet. (2010, August 6). Milli Eğitim'den bir tuhaf öneri [A weird suggestion from the Ministry of Education]. Retrieved from http:// hurarsiv.hurriyet.com.tr/goster/haber.aspx?id=15495780\& $\mathrm{tarih}=$ 2010-08-06

Jackson, D. W., \& Tein, J. (1998). Adolescents' conceptualization of adult roles: Relationships with age, gender, work goal, and maternal employment. Sex Roles, 38, 987-1008. doi:10.1023/ A:1018826626335.

Jan, C. T. G. M. E., \& Janssens, M. A. M. (1998). Maternal influences on daughters' gender role attitudes. Sex Roles, 38, 171-186. doi:10.1023/A:1018776931419.

Jung, D., \& Piccoli, W. (2001). Turkey at the crossroads. London: Zed Books.

Kagitcibasi, C. (1998). Türkiye'de kadının statüsü: Kültürlerarası perspektifler [Women's status in Turkey: Cross-cultural perspectives]. In A. Berktay (Ed.), 75 Yllda Kadınlar ve Erkekler (pp. 143-154). Istanbul: Tarih Vakfi Yayınları.

Karpiak, C. P., Buchanan, J. P., Hosey, M., \& Smith, A. (2007). University students from single-sex and coeducational schools: Differences in majors and attitudes at a Catholic university. Psychology of Women Quarterly, 31, 282-289. doi:10.1111/ j.1471-6402.2007.00371.x.

Katsurada, E., \& Sugihara, Y. (2002). Gender-role identity, attitudes toward marriage, and gender-segregated school backgrounds. Sex Roles, 47, 249-258. doi:10.1023/A:1021334710431.

Kiecolt, J. K., \& Acock, A. C. (1988). The long-term effects of family structure on gender-role attitudes. Journal of Marriage and the Family, 50, 709-717. doi:10.2307/352640.

Kirrane, M., \& Monks, K. (2008). Attitudes towards managing the work-family interface: The role of gender and social background. Irish Journal of Applied Social Studies, 8(1), 70-89.

Kiziltas, E. (2012, March 23). Kiz ve erkek liseleri; neden olmasın? [Girls' and boys' schools; why not?] Retrieved from http:// www.haber7.com/haber/20120323/Kiz-ve-erkek-liseleri-nedenolmasin.php

Koca, C., Asci, F. H., \& Demirhan, G. (2005). Attitudes toward physical education and class preferences of Turkish adolescents in terms of school gender composition. Adolescence, 40, 365-375.

Krivickas, K. M., \& Sanches, L. A. (2008). Taking a covenant to pick up his socks: Gender-traditional marriage and depression among newlywed wives and husbands. The Center for Family and Demographic Research Working Paper Series. Retrieved from http://papers.ccpr.ucla.edu/papers/PWP-BGSU-2011-010/PWPBGSU-2011-010.pdf

Kulik, L. (2002). The impact of social background on gender-role ideology: Parents' versus children's attitudes. Journal of Family Issues, 23, 53-73. doi:10.1177/0192513X02023001003.

Larsen, K. S., \& Long, E. (1988). Attitudes toward sex roles: Traditional or egalitarian? Sex Roles, 19, 1-12. doi:10.1007/BF00292459.

Lee, V. E., \& Bryk, A. S. (1986). Effects of single-sex secondary schools on student achievement and attitudes. Journal of Educational Psychology, 78, 381-385. doi:10.1037/0022-0663.78.5.381.

Lee, V. E., \& Marks, H. M. (1990). Sustained effects of the single-sex secondary school experience on attitudes, behaviors, and values in college. Journal of Educational Psychology, 82, 578-592. doi:10.1037/0022-0663.82.3.578.

Lee, V., Marks, H. M., \& Byrd, T. (1994). Sexism in single-sex and coeducational independent secondary school classrooms. Sociology of Education, 67, 92-120. doi:10.2307/2112699.

Lindsey, L. L. (1994). Gender roles: A sociological perspective. Englewood Cliffs: Prentice Hall.

Lorber, J. (2007). The social construction of gender. In D. Grusky \& S. Szelenyi (Eds.), The inequality reader (pp. 276-283). Boulder: Westview Press.
Mael, F. A. (1998). Single-sex and coeducational schooling: Relationships to socioemotional and academic development. Review of Educational Research, 68, 101-129. doi:10.3102/ 00346543068002101

Montt, G. (2012). Socioeconomic school composition effects on student outcomes. (Unpublished doctoral dissertation). University of Notre Dame, Indiana.

Ntvmsnbc. (2009, May 7). Kız okulu cinsiyetçi düzeni pekiştirir. [Girls' schools reinforce gender order]. Retrieved from http:// www.ntvmsnbc.com/id/24964484/

Phinney, J. S., \& Flores, J. (2002). "Unpackaging" acculturation: Aspects of acculturation as predictors of traditional sex role attitudes. Journal of Cross-Cultural Psychology, 33, 320-331. doi: $10.1177 / 0022022102033003007$.

Riordan, C. (2002). What do we know about the effects of single-sex schools in the private sector? Implications for public schools. In A. Datnow \& L. Hubbard (Eds.), Gender in policy and practice: Perspectives on single-sex and coeducational schooling (pp. 1030). New York: Routledge Falmer.

Sadker, M., \& Sadker, D. (1994). Failing at fairness: How our schools cheat girls? New York: Charles Scribner's Sons.

Sara-Lafosse, V. (1992). Coeducational settings and educational and social outcomes in Peru. In N. P. Stromquist (Ed.), Women and education in Latin America: Knowledge, power, and change (pp. 87-105). Boulder: Lynne Rienner Publishers.

Sax, L., Arms, E., Woodruff, M., Riggers, T., \& Eagan K. (2009). Women graduates of single-sex and coeducational high schools: Differences in their characteristics and the transition to college. UCLA Graduate School of Education \& Information Studies, 1-99. Retrieved from http://www.heri.ucla.edu/PDFs/Sax FINAL\%20REPORT Sing 1F02B4.pdf.

Signorella, M. L., Frieze, I. H., \& Hershey, S. W. (1996). Single-sex versus mixed-sex classes and gender schemata in children and adolescents. Psychology of Women Quarterly, 20, 599-607. doi:10.1111/j.1471-6402.1996.tb00325.x.

Smithers, A., \& Robinson, P. (2006). The paradox of single-sex and coeducational schooling. Retrieved from http://wordpress. buckingham.ac.uk/wp-content/uploads/2010/10/hmcsscd.pdf

Smyth, E. (2010). Single-sex education: What does research tell us? Revue française de pédagogie, 171, 47-55.

Spence, J. T., \& Hahn, E. D. (1997). The attitudes toward women scale and attitude change in college students. Psychology of Women Quarterly, 21, 17-34. doi:10.1111/j.1471-6402.1997.tb00098.x.

Sterrett, J. E., \& Bollman, S. R. (1970). Factors related to adolescents' expectations of marital roles. The Family Coordinator, 19, 353356. doi: $10.2307 / 582320$.

Suzuki, A. (1991). Egalitarian sex role attitudes: Scale development and comparison of American and Japanese women. Sex Roles, 24, 245-259. doi:10.1007/BF00288300.

Tan, M. G. (2007). Women, education and development in Turkey. In M. Carlson, A. Rabo, \& F. Gok (Eds.), Education in 'multicultural' societies-Turkish and Swedish perspectives (Vol. 18, pp. 107-122). Stockholm: Swedish Research Institute in Istanbul.

The Corporate Gender Gap Report. (2010). Retrieved from https:// members.weforum.org/pdf/gendergap/corporate2010.pdf

Turkish Statistical Institute. (2011). Labor force participation statistics April 2011. Retrieved from http://www.turkstat.gov.tr

UNDP Human Development Report (2011). Sustainability and equity: A better future for all. Retrieved from http://hdrstats.undp.org/ images/explanations/TUR.pdf

Vail, K. (2002). Same-sex schools may still get a chance. American School Board Journal, 189, 32-35.

Vatan. (2011, January 10). Lisede $45 \mathrm{~cm}$ yasağı! [45 $\mathrm{cm}$ ban in high school]. Retrieved from http://haber.gazetevatan.com/lisede-45cm-yasagi/351939/1/Haber 
Vefikulucay, D., Zeyneloglu, S., Eroglu, K., \& Taskin, L. (2007). Kafkas Üniversitesi son sinıf ögrencilerinin toplumsal cinsiyet rollerine ilişkin bakış açıları [Perceptions of and views on gender roles of senior students enrolled at Kafkas University]. Hemşirelik Yüksekokulu Dergisi, 26-38.

Wilson, W. J. (1987). The truly disadvantaged. Chicago: University of Chicago Press.
Yilmaz, D. V., Zeyneloglu, S., Kocaoz, S., Kisa, S., Taskin, L., \& Eroglu, K. (2009). Üniversite öğrencilerinin toplumsal cinsiyet rollerine ilişkin görüşleri [Views on gender roles of university students]. Uluslararasi Insan Bilimleri Dergisi, 6(1), 775-792.

Zuckerman, D. (1981). Family background, sex role attitudes, and life goals of technical college and university students. Sex Roles, 7, 1109-1126. doi:10.1007/BF00287588. 